\title{
Fertigation of 'BRS Princesa' banana with humic substance and saponin-based plant extracts
}

\author{
Diego Magalhães de Melo*1, Eugênio Ferreira Coelho², Raul Castro Carriello Rosa ${ }^{2}$, Ana Lucia Borges ${ }^{2}$, \\ Djalma Barbosa dos Santos ${ }^{3}$,Bruno Laécio da Silva Pereira ${ }^{1}$
}

10.1590/0034-737X201764040008

\begin{abstract}
The use of humic substances and plant extract has been increasing mainly in organic crop systems without scientificbased recommendations. Research is necessary to evaluate the feasibility and the recommendations of these substances. The objective of this work was to evaluate the effect of humic substances (humic and fulvic acids) applied by fertigation with and without saponin-based plant extracts on growth and yield of 'BRS Princesa' banana. The experiment was carried out using the banana cultivar 'BRS Princesa', at a spacing of $2.0 \times 2.5 \mathrm{~m}$, fertigated by drip irrigation in a Dystric Densic Xantic Ferralsol, at the Recôncavo da Bahia, Brazil. Treatments consisted of five doses of humic substances (0.0; $70 ; 105 ; 140$, and $210 \mathrm{~L} \mathrm{ha}^{-1} \mathrm{cycle}^{-1}$ ) applied with and without a saponin-based plant extract in a randomized block design in split-plot scheme. The following growth variables were evaluated: number of leaves, pseudostem height, pseudostem diameter, and length and width of the third leaf. The number of fruits/hand and hands/bunch, hand and bunch yield, and length and fruit diameter of the second central hand were evaluated during harvest. The doses of humic substances influenced only pseudostem height. Hand yield, as well as fruit length and diameter of 'BRS Princesa' banana were higher in plants fertigated with humic substance and plant extract in comparison with plants fertigated with only humic substance.
\end{abstract}

Key words: Drip irrigation; Musa spp.; organic matter; plant extracts.

\section{RESUMO}

\section{Fertirrigação da bananeira 'BRS Princesa' com substâncias húmicas e extratos vegetais a base de saponinas}

O objetivo desse trabalho foi avaliar o efeito de substâncias húmicas (ácido húmico e fúlvico) aplicadas via fertirrigação com e sem extratos vegetais a base de saponinas nas variáveis de crescimento e produção da bananeira BRS Princesa (Musa sp.). O pomar foi instalado em espaçamento de 2,0 m x 2,5 m, em Latossolo Amarelo Distrocoeso, sob regime de fertirrigação por gotejamento, no Recôncavo da Bahia, Brasil. Os tratamentos consistiram em cinco doses de substância húmicas $\left(0,0 ; 21,14 ; 31,71 ; 42,28\right.$ e $63,42 \mathrm{~L} \mathrm{ha}^{-1}$ ciclo $\left.^{-1}\right)$ com e sem aplicação de extratos vegetais, a base de saponinas. $\mathrm{O}$ delineamento experimental adotado foi o de blocos casualizados, em esquema de parcelas subdivididas no espaço com cinco repetições. Foram efetuadas análises biométricas na ocasião da floração e da colheita, sendo avaliados o crescimento e a produção acumulada, respectivamente. Mediante análise estatística foi verificado que, quando as substâncias húmicas foram associadas aos extratos vegetais, ocorreram influências significativas sobre a produtividade de pencas, comprimento e diâmetro de frutos e quando as substâncias húmicas foram aplicadas de forma isolada ocorreram efeitos significativos, apenas, sobre a altura de plantas.

Palavras-chave: Extratos de plantas; irrigação por gotejamento; matéria orgânica; Musa sp.

\footnotetext{
Submitted on February 29th, 2016 and accepted on June $06^{\text {th }}, 2017$.

${ }^{1}$ Universidade Federal do Recôncavo da Bahia, Programa de Pós Graduação em Engenharia Agrícola, Cruz das Almas, Bahia, Brasil. engdmmelo@gmail.com; bruno_laecio3@ @otmail.com ${ }^{2}$ Empresa Brasileira de Pesquisa Agropecuária, Centro Nacional de Pesquisa Mandioca e Fruticultura, Cruz das Almas, Bahia, Brasil. eugenio.coelho@embrapa.com; raul.rosa@embrapa.br; ana.borges@embrapa.br

${ }^{3}$ Universidade Federal do Recôncavo da Bahia, Programa de Pós Graduação em Ciências Agrárias, Cruz das Almas, Bahia, Brasil. djalmabsantos9@gmail.com

*Corresponding author: engdmmelo@gmail.com
} 


\section{INTRODUCTION}

Fertigation offers greater versatility for the application of fertilizers, allowing rigorous dosing of the amounts of nutrients and supplying them according to plant needs, during its development cycle (Kumar et al., 2009, Sharma et al. 2014). Fertigation with humic substances (HS) can be an interesting option to improve soil water and nutrient status leading to better plant growth (Selim and Mosa, 2012).

Humic substances are complex organic compounds of high stability and high molecular weight. They are responsible for many of the beneficial effects in the soil and in the plant, commonly attributed to the humified organic matter (Primo et al. 2011; Baldotto and Baldotto, 2014). There are reports about the mechanisms of action of HS on plants (Nardi et al., 2002; Façanha et al., 2002; Canellas et al., 2009; Canellas and Olivares, 2014; Nardi et al., 2016). Recent publication of research results involving commercial plantations is available in the literature (Ferrara and Brunetti, 2008, Hartz and Bottoms, 2010; Lima et al., 2011; Selim and Mosa, 2012; Lodhi et al., 2013). However, information is still scarce for tropical fruit crops.

Banana cultivation is susceptible to phytonematodes, with possibility of damage to the root system and significant yield losses (Ritzinger et al., 2007), and plant extracts (PE), rich in bioactive compounds such as saponins, triterpenoids, and essential oils, have repellent and intoxicating action on these organisms (D'addabbo et al., 2014).

Humic substances are used in the agricultural sector as a soil conditioner, because they favor the ionic stability of the soil solution and can promote increments in the absorption of nutrients by plants and, indirectly, in growth and production rates (Arancon et al., 2006; Pinheiro et al., 2010; Selim and Mosa, 2012). The use of plant extracts as tools of alternative pest control (Hooks et al., 2010) may cause, indirectly, the maintenance or increment in banana yield due to the conservation of the root system and, consequently, in the capacity of the plant to absorb water and nutrients from the soil solution. The association of these substances in the irrigated cultivation of banana can be advantageous, but needs technical-scientific support.

This study aimed to evaluate the effect of the application of humic substances via fertigation on the variables of growth and production of 'BRS Princesa' banana with and without the use of plant extracts.

\section{MATERIAL AND METHODS}

The experiment was carried at the experimental field of Embrapa Cassava and Tropical Fruits, located in the county of Cruz das Almas-BA, Brazil, at latitude of $12^{\circ} 48^{\prime} \mathrm{S}$, longitude of $39^{\circ} 06^{\prime} \mathrm{W}$, and altitude of $225 \mathrm{~m}$. The local climate is classified as hot humid tropical (Aw to Am), according to the Köppen-Geiger classification. Annual average records for the area were collected in the last five years (20112015) at its automatic weather station, showing maximum, minimum, and average temperatures, relative humidity, and accumulated rainfall of $29.02^{\circ} \mathrm{C}, 20.8^{\circ} \mathrm{C}, 23.9^{\circ} \mathrm{C}$, $82.8 \%$, and $1,069 \mathrm{~mm}^{-1}$ year $^{-1}$ (Melo et al. 2016). The experiment was conducted in a sand clay, Dystric Densic Xantic Ferralsol, considering the world reference base for soil resources (IUSS Working Group WRB, 2015), or Latossolo Amarelo Distrocoeso, according to the Brazilian soil classification (Santos et al. 2013). Soil physical, physical-hydraulic, and chemical attributes, in subsurface, are shown in Table 1-2.

The study was conducted in a recently installed plantation of 'BRS Princesa' banana (AAAB tetraploid, 'Maçã' type), at spacing of $2.0 \times 2.5 \mathrm{~m}$. Planting and cultural practices followed recommendations of Alves et al. (2004) and Lima and Alves (2004). Micropropagated seedlings were used. Top-dressing fertilization had basis on soil chemical analysis, through organo-mineral fertigation, with quarterly applications of monoammonium phosphate as a source of phosphorus, weekly applications of urea and potassium chloride as sources of nitrogen and potassium, respectively, and monthly application of humic substance and plant extract. The source of HS was a commercial product composed by: humic acids $\left(200 \mathrm{~g} \mathrm{~kg}^{-}\right.$ $\left.{ }^{1}\right)$, fulvic acids (102 $\left.\mathrm{g} \mathrm{kg}^{-1}\right)$, and potassium $\left(26.6 \mathrm{~g} \mathrm{~kg}^{-1}\right)$. The source of PE was a product based on the aqueous extraction of the species Yucca schidigera, Quillaja saponaria, and Tagetes spp. (93\%) and triterpenoid saponins $(7 \%)$.

Irrigation was done by a drip system with one lateral line per row and three emitters per plant with flow rate of $4.0 \mathrm{~L} \mathrm{~h}^{-1}$ each. The adopted irrigation frequency was two days. Irrigation depths were calculated based on crop evapotranspiration (ETc) in $\mathrm{mm} \mathrm{day}^{-1}$, obtained from the maximum or reference evapotranspiration (ETo), determined through the modified equation of Penman-Monteith (Allen et al., 1998). Weekly and quarterly fertigations were performed using a Venturi-type hydraulic injector and the treatments were applied using a hydraulic piston pump. Both injecting systems were connected to the controller at the beginning of the experimental area.

The experiment was conducted during the first cycle, in a randomized block design with five replicates, in splitplot scheme, with HS doses in the plot and the presence (3 $\mathrm{mL} \mathrm{plant}^{-1}$ ) or absence of plant extract in the subplot. Doses of HS were established based on the recommendation of the commercial product used, with constant concentration, considering the reference dose equivalent to $21.14 \mathrm{~L} \mathrm{ha}^{-1}$ cycle $^{-1}$, as follows: $0.0 ; 21.14 ; 31.71 ; 42.28$, and $63.42 \mathrm{~L} \mathrm{ha}^{-1}$ cycle $^{-1}$. 
The following cumulative growth attributes were evaluated: pseudostem height $(\mathrm{PH})$, pseudostem diameter (PD), number of leaves (NL), and leaf area at flowering (LAF). The attributes of cumulative production were: number of hands per bunch (NHB), number of fruits per hand (NFH), hand yield (HY), and bunch yield (BY), in t $\mathrm{ha}^{-1}$. Pseudostem height was measured from the soil to the apex of the plant; pseudostem diameter was considered as the circumference at $0.20 \mathrm{~m}$ from the soil surface, and maximum length and width of the third leaf, for the determination of leaf area, was determined according to Zucoloto et al. (2008) at the beginning of the flowering stage.

During the flowering stage, root samples were collected by the monolith method (Bohm, 1979). Soil-root samples with dimensions of $0.10 \times 0.10 \times 0.10 \mathrm{~m}$ were collected in two soil pits in the direction of the plant row: one close to pseudostems of the subplot under the HS + PE application and one close to pseudostems of the subplot without PE application, i.e., only HS application. The samples were collected at distances of 0.25 and $0.50 \mathrm{~m}$ from the pseudostems and at depths of $0.10,0.20,0.30$, and $0.40 \mathrm{~m}$ in the subplots under HS and HS + PE application. The processing of the samples involved separation of roots from soil, scanning, and determination of root length and root length density according to Santana et al. (2012).

Results of plant growth, production, and root length were subjected to analysis of variance and the independent variables that affected the dependent ones were compared by mean test and regression analysis were performed for the evaluation of quantitative variable (HS doses). Statistical analyses used SISVAR software (Ferreira, 2011).

\section{RESULTS AND DISCUSSION}

According to the analysis of variance, there was a significant effect of HS doses only on pseudostem height $(\mathrm{PH})(\mathrm{p}<0.05)$ and no significant effect $(\mathrm{p}>0.05)$ of $\mathrm{PE}$ or the interaction $\mathrm{HS} \times \mathrm{PE}$ on the variables $\mathrm{PD}, \mathrm{NL}$, and LAF was detected. There was no mathematical model in which the variation in HS doses could adequately explain the slight variation of pseudostem height (Figure 1).

The absolute means of PH, as well as PD, NL, and LAF (Table 3), were close to those reported by Roque et al. (2014), who agronomically evaluated an irrigated cultivation of 'BRS Princesa' banana in the same region with the use of solid fertilization and without the use of humic substances.

The absence of effects on banana growth can be related to the response time of the soil to the application of HS, which acted as conditioners of soil chemical and physical quality, improving its capacity of ion exchange, availability of nutrients, and structure (Selim and Mosa, 2012; Coelho et al. 2016), but without directly supplying nutrients, such as organic matter in less advanced stages of decomposition, so that their action on plant nutrition and growth is indirect and does not occur immediately. Therefore, their effects may take a longer time in comparison with fertilizers industrially produced for rapid incorporation of nutrients

Table 1: Chemical attributes of the Dystric Densic Xantic Ferralsol in the experimental area in Cruz das Almas-BA, Brazil, 2013

\begin{tabular}{|c|c|c|c|c|c|c|c|}
\hline \multirow{2}{*}{$\begin{array}{l}\text { Layer } \\
(\mathrm{m})\end{array}$} & Sand & Silt & Clay & \multirow{2}{*}{$\frac{\text { Ds }}{\left(\mathrm{g} \mathrm{cm}^{-3}\right)}$} & \multicolumn{3}{|c|}{$\mathbf{U}\left(\mathrm{cm}^{3} \mathrm{~cm}^{-3}\right)$} \\
\hline & & $\left(\mathrm{g} \mathrm{kg}^{-1}\right)$ & & & $10 \mathrm{kPa}$ & $33 \mathrm{kPa}$ & $1500 \mathrm{kPa}$ \\
\hline $0-0.2 \mathrm{~m}$ & 732 & 87 & 181 & 1.6 & 0.1785 & 0.1761 & 0.0980 \\
\hline $0.2-0.4 \mathrm{~m}$ & 629 & 68 & 303 & 1.6 & 0.1964 & 0.1936 & 0.1514 \\
\hline $0.4-0.7 \mathrm{~m}$ & 600 & 77 & 323 & 1.4 & 0.1896 & 0.1637 & 0.1320 \\
\hline
\end{tabular}

Ds: Soil bulk density; U: retained soil moisture.

Table 2: Soil physical and physical-hydraulic attributes of the Dystric Densic Xantic Ferralsol in the experimental area in Cruz das Almas-BA, Brazil, 2013

\begin{tabular}{|c|c|c|c|c|c|c|}
\hline Layer & \multirow{2}{*}{ pH (water) } & $\mathbf{P}$ & $\mathbf{K}^{+}$ & $\mathrm{Ca}^{++}$ & $\mathbf{M g}^{++}$ & $\mathbf{A l}^{3+}$ \\
\hline$(\mathbf{m})$ & & \multicolumn{5}{|c|}{$\left(\mathrm{mg} \mathrm{dm}^{-3}\right)$} \\
\hline $0.0-0.2 \mathrm{~m}$ & 6.7 & 15.6 & 0.14 & 2.5 & 0.9 & 0.2 \\
\hline $0.2-0.4 \mathrm{~m}$ & 6.0 & 6.0 & 0.10 & 1.7 & 0.7 & 0.1 \\
\hline $0.4-0.7 \mathrm{~m}$ & 5.4 & 4.6 & 0.07 & 1.1 & 0.5 & 0.0 \\
\hline Layer & $\mathrm{Na}$ & $\mathbf{H}^{+} \mathbf{A l}^{3+}$ & SB & CEC & $\mathbf{V}$ & OM \\
\hline (m) & \multicolumn{4}{|c|}{$\left(\mathrm{cmol}_{\mathrm{c}} \mathrm{dm}^{-3}\right)$} & $(\%)$ & $\left(\mathrm{g} \mathrm{kg}^{-1}\right)$ \\
\hline $0.0-0.2 \mathrm{~m}$ & 0.03 & 0.7 & 3.6 & 4.3 & 84 & 7.0 \\
\hline $0.2-0.4 \mathrm{~m}$ & 0.03 & 1.4 & 2.5 & 3.9 & 64 & 5.9 \\
\hline $0.4-0.7 \mathrm{~m}$ & 0.02 & 1.9 & 1.7 & 3.6 & 47 & 5.7 \\
\hline
\end{tabular}

SB: sum of exchangeable bases; CEC: cation exchange capacity; V: base saturation; OM: soil organic matter. 
in the soil solution and plant tissues, which can be one of the reasons for the lack of influence of HS dose with and without PE in most of the growth variables recorded in the first crop cycle.

In addition, the responses to the applications of HS and PE may depend on other factors such as the composition of the substances present in the extracts (Hooks, et al 2010). Besides, the nature of these organic compounds is relatively complex and there is unconsolidated knowledge on the action of the humic fraction on plants due to its composition and chemical structure, which has not been elucidated and is variable (Baldotto and Baldotto, 2014). Another aspect is the doses of HS application, which may not have been sufficient to promote positive responses on banana plants (Hartz and Bottoms, 2010; Lodhi et al., 2013; Coelho et al., 2016; Melo et al., 2016).

In relation to the analysis of variance of banana production variables, there was no significant effect ( $\mathrm{p}>$ 0.05) of the interaction between HS and PE doses. On the other hand, there was significant effect of HS application on the number of NHB and HS + PE application on HY, BY, and length (LCF) and diameter (DCF) of the central fruit of the second hand. Means of production variables for the HS doses applied in association with PE are shown in Table 4.

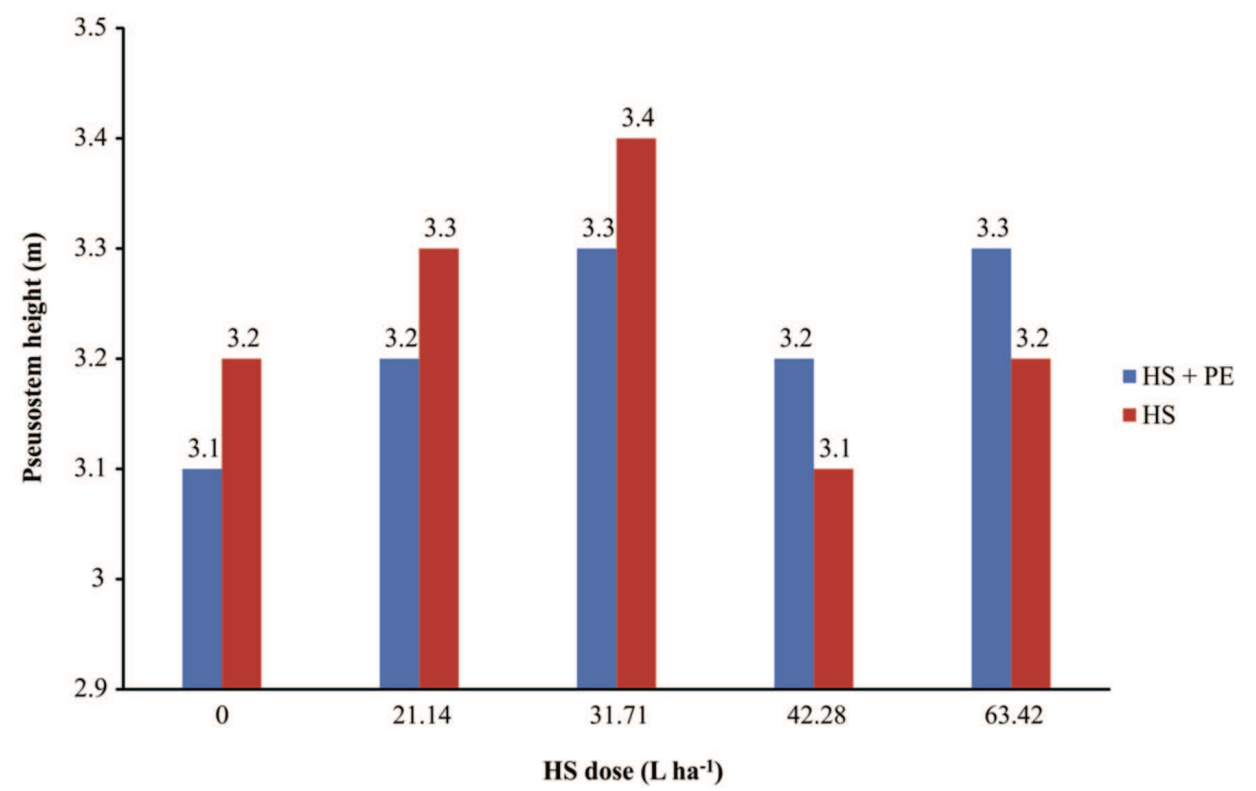

Figure 1: Mean pseudostem height recorded for the different doses of humic substances (HS) and plant extracts (PE, fixed dose of $3 \mathrm{~mL})$.

Table 3: Absolute means of all treatments with PE application (HS + PE) and without PE application (HS) of banana growth variables

\begin{tabular}{|c|c|c|c|c|}
\hline \multicolumn{5}{|c|}{$\mathbf{H S}+\mathbf{P E}$} \\
\hline $\begin{array}{l}\text { Doses } \\
\left(\text { L ha }^{-1}\right)\end{array}$ & $\begin{array}{l}\text { PH } \\
(\mathbf{m})\end{array}$ & $\begin{array}{l}\text { PD } \\
(\mathbf{m})\end{array}$ & $\begin{array}{c}\text { NL } \\
\text { (unit) }\end{array}$ & $\begin{array}{l}\text { LAF } \\
\left(\mathbf{m}^{2}\right)\end{array}$ \\
\hline 0.0 & 3.10 & 0.29 & 10.00 & 9.61 \\
\hline 21.14 & 3.20 & 0.29 & 11.00 & 9.61 \\
\hline 31.71 & 3.30 & 0.25 & 10.00 & 9.61 \\
\hline 42.28 & 3.20 & 0.29 & 9.00 & 9.61 \\
\hline 63.42 & 3.30 & 0.25 & 10.00 & 9.61 \\
\hline \multicolumn{5}{|c|}{ HS } \\
\hline $\begin{array}{l}\text { Doses } \\
\left(\mathbf{L ~ h a}^{-1}\right)\end{array}$ & $\begin{array}{l}\text { PH } \\
\text { (m) }\end{array}$ & $\begin{array}{l}\text { PD } \\
\text { (m) }\end{array}$ & $\begin{array}{c}\text { NL } \\
\text { (unit) }\end{array}$ & $\begin{array}{l}\text { LAF } \\
\left(\mathbf{m}^{2}\right)\end{array}$ \\
\hline 0.0 & 3.20 & 0.29 & 10.00 & 9.61 \\
\hline 21.14 & 3.30 & 0.25 & 10.00 & 9.62 \\
\hline 31.71 & 3.44 & 0.29 & 10.00 & 9.61 \\
\hline 42.28 & 3.10 & 0.25 & 9.00 & 9.61 \\
\hline 63.42 & 3.20 & 0.25 & 10.00 & 9.62 \\
\hline
\end{tabular}

PE: plant extract; HS: humic substances; PH: pseudostem height; PD: pseudostem diameter; NL: number of leaves; LAF: leaf area at flowering. 
Despite the significant effect of the application of the substances for the variable NHB, the mean absolute values recorded remained very similar, slightly differing from each other, so that the isolated application of HS did not have expressive results on yield, with absolute means very close to those of the control treatment. This corroborates the results reported by Melo et al. (2016), who studied monthly HS application, through microsprinkler irrigation, in a fertigated cultivation of the same banana cultivar and observed no significant effect on any of the production variables, or even statistical differences between the absolute means of the treatments and the control.

On the other hand, this behavior differs from that recorded for the treatments with $\mathrm{HS}+\mathrm{PE}$ application and the variables HY, LCF, and DCF were sensitive to the applied treatments. The absolute means of HY observed in this study, for the production variables, are higher than those reported by Roque et al. (2014). According to the F test of the analysis of variance, the absolute means of HY, LCF, and DCF were statistically superior to the absolute means of the treatments without PE application (Table 5). Plant extract application in combination with HS caused relative increases in hand yield and fruit length and diameter of about $1.69 \mathrm{tha}^{-1}$ (6.53\%), $0.96 \mathrm{~cm}$ (5.69\%), $1.34 \mathrm{~cm}(3.78 \%)$, respectively, in relation to the isolated application of HS.

The increase in banana yield is due to the higher means of fruit length and diameter, which promoted greater weight compared with plants under isolated application of HS. Also, this result might be due to the total root length evaluated in the soil profile in the layer of $0-0.40 \mathrm{~m}$ which was larger for the use of PE with HS except for the HS dose of 42.28 $\mathrm{L} \mathrm{ha}^{-1}$ (Table 6). The absolute root length means (RL) by using PE with HS were larger than RL without using PE even for those doses in which RL did not show statistical difference. This application of PE stimulates growth action on the root system and provides a biocide action on harmful organisms, such as nematodes, as reported by Hooks et al. (2010). This fact possibly conditioned the preservation of the root system

Table 4: Mean values for the production attributes' ${ }^{1}$ of 'BRS Princesa" banana

\begin{tabular}{|c|c|c|c|c|c|c|}
\hline $\begin{array}{l}\text { Dose } \\
\left(\mathbf{L} \text { ha }^{-1}\right)\end{array}$ & $\begin{array}{l}\text { NFH } \\
\text { (unit) }\end{array}$ & $\begin{array}{l}\text { NHB } \\
\text { (unit) }\end{array}$ & $\begin{array}{c}\text { HY } \\
\left(t \text { ha }^{-1}\right)\end{array}$ & $\begin{array}{c}\text { BY } \\
\left(t \text { ha }^{-1}\right)\end{array}$ & $\begin{array}{l}\text { LCF } \\
(\mathrm{cm})\end{array}$ & $\begin{array}{l}\text { DCF } \\
(\mathrm{mm})\end{array}$ \\
\hline 0.0 & 97.90 & 6.07 & 25.52 & 29.10 & 17.10 & 36.03 \\
\hline 21.14 & 103.25 & 6.57 & 27.83 & 31.75 & 16.70 & 36.90 \\
\hline 31.71 & 101.50 & 6.47 & 27.27 & 30.87 & 17.60 & 36.25 \\
\hline 42.28 & 102.40 & 6.50 & 27.44 & 30.93 & 18.50 & 35.20 \\
\hline 63.42 & 99.60 & 6.32 & 25.53 & 29.11 & 17.10 & 36.23 \\
\hline $\mathrm{CV}(\%)$ & 9.54 & 5.09 & 8.47 & 7.88 & 8.89 & 5.44 \\
\hline
\end{tabular}

${ }^{1}$ Number of fruits/hand (NFH); number of hands/bunch (NHB); hand yield (HY, t ha $\left.{ }^{-1}\right)$; bunch yield $\left(\mathrm{BY}, \mathrm{t} \mathrm{ha}^{-1}\right)$; length $(\mathrm{LCF}, \mathrm{cm})$ and diameter $(\mathrm{DCF}, \mathrm{cm})$ of the central fruit of the second hand, and the coefficient of variation $(\mathrm{CV})$.

Table 5: Absolute means of all treatments with PE application (HS + PE) and without PE application (HS) and the coefficient of variation $(\mathrm{CV})$ of the variables ${ }^{1}$ analyzed

\begin{tabular}{lcccccc}
\hline Plant extracts & $\begin{array}{c}\text { NFH } \\
(\mathbf{u n i t})\end{array}$ & $\begin{array}{c}\text { NHB } \\
(\mathbf{u n i t})\end{array}$ & $\begin{array}{c}\text { HY } \\
\left(\mathbf{t ~ h a}^{-1}\right)\end{array}$ & $\begin{array}{c}\text { BY } \\
\left(\mathbf{t ~ h a}^{-1}\right)\end{array}$ & $\begin{array}{c}\text { LCF } \\
(\mathbf{c m})\end{array}$ & $\begin{array}{c}\text { DCF } \\
(\mathbf{m m})\end{array}$ \\
\hline HS + PE & $101.10 \mathrm{a}$ & $6.42 \mathrm{a}$ & $27.56 \mathrm{a}$ & $31.34 \mathrm{a}$ & $17.89 \mathrm{a}$ & $36.79 \mathrm{a}$ \\
$\mathrm{HS}$ & $100.70 \mathrm{a}$ & $6.36 \mathrm{a}$ & $25.87 \mathrm{~b}$ & $29.35 \mathrm{a}$ & $16.88 \mathrm{~b}$ & $35.45 \mathrm{~b}$ \\
\hline $\mathrm{CV}(\%)$ & 3.63 & 7.53 & 5.33 & 4.82 & 8.21 & 5.59 \\
\hline
\end{tabular}

PE - plant extract; HS - humic substances.

${ }^{1}$ Number of fruits/hand (NFH, unit); number hands/bunch (NHB, unit); hand yield ( $\left.\mathrm{HY}, \mathrm{t} \mathrm{ha}^{-1}\right)$; bunch yield (BY, tha $\left.{ }^{-1}\right)$; and length (LCF, cm) and diameter (DCF, $\mathrm{cm}$ ) of the central fruit of the second hand.

Means followed by the same letters in the column do not differ by $\mathrm{F}$ test at 0.05 probability level.

Table 6: Comparison of means of root length (RL) as a function of the application of humic substances (HS), with and without plant extracts (PE), through fertigation

\begin{tabular}{lcccc}
\hline \multicolumn{5}{c}{ HS doses $\left(\mathbf{L ~ h a ~}^{-1}\right)$} \\
\hline PE & $\mathbf{0}$ & $\mathbf{3 1 . 7 1}$ & $\mathbf{4 2 . 2 8}$ & $\mathbf{6 3 . 4 2}$ \\
\hline With & $372.5 \mathrm{a}$ & $473.1 \mathrm{a}$ & $385.2 \mathrm{a}$ & $347.3 \mathrm{a}$ \\
Without & $367.2 \mathrm{a}$ & $307.6 \mathrm{~b}$ & $375.2 \mathrm{a}$ & $294.6 \mathrm{~b}$ \\
\hline
\end{tabular}

Means followed by the same letters in the column do not differ by $\mathrm{F}$ test at 0.05 probability level. 
and stimulated root growth inducing greater amplitude in the water and nutrient extraction. The lack of expressive responses of HS application on the banana root system is relatively different from the behavior of other crops (Cooper et al., 1998; Canellas et al., 2009; Silva etal., 2011).

\section{CONCLUSIONS}

The isolated application of humic substances promotes significant results on the height of banana plants.

The additional application of plant extracts have positive and significant effect on root system and yield variables such as hand yield and fruit length and diameter of 'BRS Princesa' banana, during its first production cycle.

\section{REFERENCES}

Allen RG, Pereira LS, Raes D \& Smith M (1998) Crop evapotranspiration: guidelines for computing crop water requirements. Rome, FAO Irrigation and Drainage. 300p.

Arancon NQ, Edwards CA, Lee S \& Byrne R (2006) Effects of humic acids from vermicomposts on plant growth. European Journal of Soil Biology, 42:65-69.

Baldotto MA \& Baldotto LEB (2014) Ácidos húmicos. Revista Ceres, 61:856-881

Bohm W (1979) Methods of studying root systems. New York, Springer Verlag Berlin Heidelberg. 190p.

Alves EJ, Lima MB, Carvalho JEB \& Borges AL (2004) Tratos culturais e colheita. In: Borges AL \& Souza LS (Eds.) O cultivo da bananeira. Cruz das Almas, Editora Embrapa Mandioca e Fruticultura. p.107-131.

Canellas LP, Spaccini R, Piccolo A, Dobbss LB, Okorokova-Façanha A, Santos GA, Olivares FL \& Façanha AR (2009) Relationships between chemical characteristics and root growth promotion of humic acids isolated from Brazilian Oxisols. Soil Science, 174:611-620.

Canellas LP \& Olivares FL (2014) Physiological responses to humic substances as plant growth promoter. Chemical and Biological Technologies in Agriculture, 1:01-11.

Coelho EF, Melo DM, Pereira BLS, Santos DB \& Rosa RCC (2016) Roots of 'BRS Princesa'banana fertigated with humic substances and saponin-based plant extracts. Acta Scientiarum. Agronomy, 38:521-528.

Cooper RJ, Liu C \& Fischer DS (1998) Influence of humic substances on rooting and nutrient content of creeping bentgrass. Crop Science, 38:1639-1644.

D'addabbo T, Laquale S, Lovelli S, Candido V \& Avato P (2014) Biocide plants as a sustainable tool for the control of pests and pathogens in vegetable cropping systems. Italian Journal of Agronomy, 9:137-145.

Kumar A, Kumar A, Singh HK, Kumari N \& Kumar P (2009) Effect of fertigation on banana biometric characteristics and fertilizer use efficiency. Journal of Agricultural Engineering, 46:27-31

Façanha AR, Façanha ALO, Olivares FL, Guridi F, Santos GA, Velloso ACX, Rumjanek VM, Brasil F, Schripsema J, Braz-Filho R, Oliveira MA \& Canellas LP (2002) Bioatividade de ácidos húmicos: efeitos sobre o desenvolvimento radicular e sobre a bomba de prótons da membrana plasmática. Pesquisa Agropecuária Brasileira, 37:1301-1310.
Ferrara G \& Brunetti G (2008) Influence of foliar applications of humic acids on yield and fruit quality of table grape cv. Itália. Journal International Sciences de la Vigne et du Vin, 42:79-87.

Ferreira DF (2011) Sisvar: a computer statiscal analysis system. Ciência e Agrotecnologia, 35:1039-1042.

Hartz TK \& Bottoms TG (2010) Humic substances generally ineffective in improving vegetable crop nutrient uptake or productivity. HortScience, 45:906-910.

Hooks CR, Wang KH, Ploeg A \& Mcsorley R (2010) Using marigold (Tagetes spp.) as a cover crop to protect crops from plantparasitic nematodes. Applied Soil Ecology, 46:307-320.

IUSS Working Group WRB (2015) World Reference Base for Soil Resources 2014. Rome, FAO World soil resources reports. 188p.

Lima AA, Alvarenga MAR, Rodrigues L \& Carvalho JG (2011) Concentração foliar de nutrientes e produtividade de tomateiro cultivado sob diferentes substratos e doses de ácidos húmicos. Horticultura Brasileira, 29:63-69.

Lima MB \& Alves EJ (2004) Estabelecimento do pomar. In: Borges AL \& Souza LS (Eds.) O cultivo da bananeira. Cruz das Almas, Editora Embrapa Mandioca e Fruticultura. p.87-106.

Lodhi A, Tahir S, Iqbal Z, Mahmood A, Akhtar M, Qureshi TM, Yaqub M \& Naeem A (2013) Characterization of commercial humic acid samples and their impact on growth of fungi and plants. Soil Environment, 32:63-70.

Melo DM, Coelho EF, Borges AL, Pereira LSP \& Campos MS (2016) Agronomic performance and soil chemical attributes in a banana tree orchard fertigated with humic substances. Pesquisa Agropecuária Tropical, 46:421-428.

Nardi S, Pizzeghello D, Muscolo A \& Vianello A (2002) Physiological effects of humic substances on higher plants. Soil Biology and Biochemistry, 34:1527-1536.

Nardi S, Pizzeghello D, Schiavon M \& Ertani A (2016) Plant biostimulants: physiological responses induced by protein hydrolyzed-based products and humic substances in plant metabolism. Scientia Agricola, 73:18-23.

Pinheiro GL, Silva CA \& Furtini Neto AE (2010) Crescimento e nutrição de clone de eucalipto em resposta à aplicação de concentrações de C-ácido húmico. Revista Brasileira de Ciência do Solo, 34:1217-1229.

Primo DC, Menezes RC \& Silva TO (2011) Substâncias húmicas da matéria orgânica do solo: uma revisão de técnicas analíticas e estudos no nordeste brasileiro. Scientia Plena, 7:01-13.

Ritzinger CHSP, Borges AL, Ledo CAS \& Caldas RC (2007) Fitonematóides associados a bananais 'Pacovan' sob condição de cultivo irrigado: relação com a produção. Revista Brasileira de Fruticultura, 29:677-680.

Roque RL, Amorim TB, Ferreira CF, Ledo CAS \& Amorim EP (2014) Desempenho agronômico de genótipos de bananeira no recôncavo da Bahia. Revista Brasileira de Fruticultura, 36:598609.

Santana JAV, Coelho EF, Faria MA, Silva EL \& Donato SLR (2012) Distribuição de raízes de bananeira "Prata- Anã" no segundo ciclo de produção sob três sistemas de irrigação. Revista Brasileira de Fruticultura, 34:124-132.

Santos HG, Jacomine PKT, Anjos LHC, Oliveira VA, Lumbreras JF, Coelho MR, Almeida JA, Cunha TJF \& Oliveira JB (2013) Sistema brasileiro de classificação de solos. $3^{\text {a }}$ ed. Brasília, Embrapa. 353p.

Selim E \& Mosa AA (2012) Fertigation of humic substances improves yield and quality of broccoli and nutrient retention in a sandy soil. Journal of Plant Nutrition and Soil Science, 175:273281. 
Silva AC, Canellas LP, Olivares FL, Dobbss LB, Aguiar NO, Frade DOR, Rezende CE \& Peres LEP (2011) Promoção do crescimento radicular de plântulas de tomateiro por substâncias húmicas isoladas de turfeiras. Revista Brasileira de Ciência do Solo, 35:1609-1617.

Sharma R, Bhardwaj S \& Choudhary M (2014) Fertigation on Fruit Crops: A Review. Annals of Biology, 30:48-53.
Zucoloto M, Lima JSS \& Coelho RI (2008) Modelo matemático para estimativa da área foliar total de bananeira 'Prata-Anã'. Revista Brasileira de Fruticultura, 30:1152-1154. 